\title{
EFEKTIFITAS MEDIA ALAM DALAM PEMBELAJARAN PENDIDIKAN AGAMA ISLAM (PAI) DI SEKOLAH ALAM UNGARAN (SAUNG) KABUPATEN SEMARANG
}

\author{
Faldin Baen, M.Pd.I
}

\begin{abstract}
This study aims to describe the natural media in learning Islamic religious education (PAI) in SAUNG. In addition, this research was also conducted to explain the effectiveness of natural media in learning Islamic religious education at SAUNG schools. The focus of the problem in this study included: (I) Utilization of natural media in the learning of Islamic religious education (PAI) at the ungaran (SAUNG) natural school, (2) Effectiveness of natural media in learning Islamic education (PAI).

This research uses descriptive analytical method with data collection techniques in the form of interviews, observation and documentation. Data that has been collected will be analyzed by means of data reduction, data presentation and conclusion drawing. From the results of research in the field it was found that the utilization of natural media is done by applying the learning tools implemented under the program MABIT, outting, outbound, cooking and gardening. The effectiveness of natural media in teaching Islamic religious education (PAI) in nature school Ungaran (SAUNG) managed to make children feel comfortable to learn PAI and produce good cognitive value. The conclusion of the study was the use of natural media in teaching Islamic religious education (PAI) in nature school Ungaran (SAUNG) is done in some programs, namely MABIT, outting, outbound, cooking and gardening. This makes children feel comfortable in the study of Islamic religious education (PAI) and managed to increase the value of cognition in children.
\end{abstract}

Key Words: Natural Media, Islamic Religious Education, Natural School of Ungaran (SAUNG)

ABSTRAK

Penelitian ini bertujuan untuk mendeskripsikan media alam dalam pembelajaran pendidikan agama Islam (PAI) di sekolah alam ungaran. Selain itu penelitian ini juga dilakukan untuk menjelaskan efektifitas media alam dalam pembelajaran pendidikan agama Islam di sekolah SAUNG. Fokus masalah dalam penelitian ini, meliputi: (I) Pemanfaatan media alam dalam pembelajaran pendidikan agama Islam (PAI) di sekolah alam ungaran (SAUNG), (2) Efektifitas media alam dalam pembelajaran pendidikan agama Islam (PAI).

Penelitian ini menggunakan metode deskriptif analitis dengan teknik pengumpulan data 
berupa wawancara, observasi dan dokumentasi. Data yang telah dikumpulkan maka akan dianalisis dengan cara reduksi data, penyajian data dan penarikan kesimpulan. Hasil penelitian ditemukan bahwa pemanfaatan media alam dilakukan dengan cara menerapkan perangkat pembelajaran yang dilaksanakan berdasarkan program MABIT (malam bina iman dan taqwa), outting, outbond, cooking dan berkebun. Efektifitas media alam dalam pembelajaran Pendidikan Agama Islam (PAI) di sekolah alam ungaran (SAUNG) berhasil membuat anak-anak merasa nyaman untuk mempelajari PAI dan menghasilkan nilai kognitif yang baik.

Kata Kunci: Media alam, Pendidikan Agama Islam, Sekolah Alam Ungaran (SAUNG) 
A. PENDAHULUAN

Sekolah menjadi wadah untuk meningkatkan kualitas pendidikan anak. Untuk itu, peran media dalam proses pembelajaran di dalam kelas akan membantu siswa dalam memahami materi yang diberikan oleh guru di sekolah. Teori ini didukung oleh Umar yang mengutip pendapat A.Tabrani Rusyan dan Yani Daryani dalam Jurnal Tarbawiwah (2013:127) bahwa salah satu cara yang dapat ditempuh ialah menciptakan situasi belajar yang memungkinkan terjadinya pengalaman belajar pada diri siswa yang melibatkan segala sumber belajar.

Selain itu pembentukan karakter yang baik dalam Undang-undang nomor 20 tahun 2003 tentang sistem pendidikan nasional pasal 36 ayat 2 menyatakan bahwa kurikulum pada semua jenjang dan jenis pendidikan dikembangkan sesuai dengan satuan pendidikan dan dikembangkan dengan prinsip diversifikasi sesuai dengan satuan pendidikan, potensi daerah dan peserta didik (Kementerian Pendidikan Nasional, 2003:I0). Regulasi yang telah diberikan oleh pemerintah bertujuan untuk membuka kreatifitas pelaku pendidikan untuk melakukan perubahan yang lebih baik. Hal ini sekaligus menghilangkan lemahnya para pendidik dalam mencari media yang baik dalam mengajar di sekolah.

Kelemahan yang sering terjadi di dunia pendidikan indonesia ialah pemanfaatan konsep yang jauh lebih luas dibandingkan praktek guna memunculkan skill peserta didik. Di lain pihak, Sekolah ialah tempat untuk semua siswa yang memiliki bakat terpendam dan siswa diwajibkan untuk belajar dari semua hal yang diperlukan untuk mengembangkan kemampuan yang mereka miliki (Komunitas sekolah alam,
2005:9). Selain itu, sekolah terkadang mengasah kemampuan kognitif anak lalu melupakan kemampuan afektif dan psikomotorik. Hal ini terjadi karena media pembelajaran guru belum mampu menstimulus kemampuan siswa. Media yang digunakan bersifat kaku dan monoton turut menciptakan kebosanan dalam diri siswa di sekolah. Akibat terparah yang dirasakan siswa adalah sekolah tidak lagi menjadi tempat untuk meraih masa depan yang baik dan merubah karakter seseorang.

Guna mencegah munculnya berbagai masalah dalam melakukan kegiatan belajar mengajar di sekolah. Sekolah Alam Ungaran (SAUNG) melakukan proses pembelajaran dengan menggunakan media alam. Media alam disusun berdasarkan beberapa program seperti MABIT, cooking, outing, out bond dan berkebun. Selain itu sekolah alam ungaran tidak menggunakan kelas dalam proses belajar. Kelas hanya digunakan untuk belajar di saat proses pembelajaran mengharuskan di dalam kelas. Kelas dihias dengan menggunakan bambu dan kayu yang dikelilingi pepohonan yang didesain semi terbuka (Zuhrotun Nafisah, 2010:57). Hal ini dilakukan agar penerapan media alam dapat dipraktekan dengan baik oleh siswa karena kelas memiliki tempat yang lapang dan luas. Hal ini juga akan menumbuhkan kenyamanan bagi siswa untuk belajar di sekolah dan guru dapat mengaplikasikan media alam yang diajarkanya dengan baik.

Dalam pembentukan karakter siswa yang baik maka sekolah alam menjadikan nilainilai Islam sebagai bagian untuk mewujudkan cita-cita tersebut. Mata pelajaran pendidikan agama Islam akan diintegrasikan pada semua mata pelajaran. Hal ini membuat media alam 
yang digunakan oleh guru turut menggunakan mata pelajaran pendidikan agama Islam sebagai bagian yang tidak terpisahkan bagi siswa. Untuk itu guru harus memiliki kecakapan dalam menumbuhkan potensi siswa dengan tidak meninggalkan nilai-nilai Islam dalam setiap tema yang diajarkan. Suhendi dan Septriana (20I2:77) menjelaskan bahwa guruguru sekolah alam harus memiliki bahasa ibu yang berarti sayang kepada setiap anak, lalu guru wajib memahami Al Qur'an dan hadist serta guru hendaknya menguasai ilmu yang diampunya. Konsep ini membuka paradigma baru agar guru tidak meninggalkan ilmu agama Islam dalam setiap pembelajaran yang diberikan kepada siswa. Guru harus menyadari bahwa siswa dididik untuk menjadi khalifah fil ard yang selalu menyadari posisinya sebagai hamba Allah Swt.

Untuk itu sekolah alam ungaran (SAUNG) telah menjadi salah satu pilihan dalam inovasi pendidikan bagi anak. Sekolah Alam yang tidak hanya menjadikan Alam sebagai media pembelajaran. Akan tetapi, alam juga mampu mengenalkan keluasan penciptaan Allah kepada manusia, memberikan pengaruh ruhiyah kepada peserta didik dalam menanamkan nilai-nilai Islam. Dengan begitu, para penggagas sekolah, kepala sekolah, guru dan wali murid sekolah alam menganggap bahwa hakikat tujuan pendidikan adalah membantu anak didik tumbuh menjadi manusia yang berkarakter. Menjadi menusia yang tidak saja mampu memanfaatkan apa yang tersedia di alam, tetapi juga mampu mencintai dan memelihara lingkungannya. Pengetahuan bukanlah barang yang harus kita miliki. Pengetahuan adalah sebuah fungsi. Sebagai sebuah fungsi, kita harus mempelajari semua pengetahuan yang membantu siswa berubah menjadi lebih baik. Landasan inilah yang membedakan secara filosofis dengan pendidikan pada umumnya. Dimana Sekolah Alam menciptakan pembelajaran di luar kelas dengan mengintegrasikan mata pelajaran PAI dan mata pelajaran umum.

\section{B. METODE PENELITIAN}

Penelitian ini menggunakan pendekatan kualitatif dengan latar alami (Natural Setting) sebagai sumber data dan langsung membahas media pembelajaran Pendidikan Agama Islam dengan segmentasi alam di SD Alam Ungaran. Dasar penelitian ini adalah fenomenologis karena tugas peneliti adalah memaknai atau memberikan interpretasi terhadap gejala atau fenomena yang memancar dari objek penelitian.

Dalam melakukan analisis data, Peneliti menggunakan metode Triangulasi data yaitu metode dengan teknik pemeriksaan keabsahan data yang memanfaatkan sesuatu yang lain. Dalam proses pengumpulan data, peneliti menggunakan teknik tiga teknik yaitu wawancara, observasi dan studi dokumentasi.

\section{PEMBAHASAN}

I. Pemanfaatan Media Alam dalam Pembelajaran PAI Di SD Alam Ungaran

Menggunakan alam sebagai media pembelajaran SD Alam Ungaran telah memberikan informasi baru bahwa kreatifitas dalam menyusun perangkat pembelajaran dapat dilakukan di alam sebagai bagian dari kehidupan. Hal ini kadang kurang disadari oleh banyak orang khususnya guru dalam menyusun perangkat pembelajaran di sekolah. Untuk itulah SD Alam ungaran didirikan dengan keyakinan bahwa proses pembelajaran dapat dilakukan 
di alam sebagai bagian yang tidak terpisahkan dalam kehidupan manusia.

Guna mewujudkan hal tersebut maka pihak sekolah merancang letak bangunan sekolah yang langsung bersentuhan dengan pegunungan, perbukitan dan hutan serta tepat berada di tengah-tengah masyarakat. Hal ini bertujuan agar siswa dapat melihat fenomena alam yang sangat indah sekaligus bertafakur akan penciptaan Allah SWT. Manfaat lain yang dapat diterima siswa adalah memunculkan kecintaan terhadap alam hingga mereka memahami bahwa alam memiliki fungsi yang sangat penting. Fungsi yang dapat menyelamatkan kehidupan manusia sekaligus menjadi sumber kehidupan. Selain itu letak sekolah yang jauh dari aktifitas perkotaan memberikan kemudahan bagi anak untuk memahami pelajaran. Suasana pegunungan yang hening tanpa suara bising kendaraan dapat menjaga kosentrasi siswa dalam belajar. Begitu pula dengan udara yang sejuk tanpa harus membeli $\mathrm{AC}$ atau alat pendingin lainya seperti yang biasa diterapkan di berbagai sekolah. Hal ini menjelaskan bahwa implementasi media alam diawali dengan letak topografi sekolah. Semakin dekat sekolah dengan sumber media maka akan mempermudah siswa untuk memahami makna media tersebut. Selain itu letak sekolah yang benar-benar berada di pegunungan akan memudahkan guru dalam menerapkan media alam pada proses pembelajaran.

Mendekatkan anak dengan alam juga akan berhasil jika perangkat pembelajaran yang digunakan dalam proses pembelajaran dibuat dengan menyesuaikan kondisi alam. Maka membuat kurikulum khusus untuk merancang media alam menjadi salah satu syarat pertama untuk mewujudkan pembelajaran di alam. Kurikulum khusus bukan berarti membuat kurikulum baru yang tidak berkaitan langsung dengan kurikulum yang telah dibuat oleh kementerian pendidikan nasional. Akan tetapi kurikulum khusus ialah kurikulum yang dikembangkan berdasarkan kurikulum yang telah dibuat oleh pemerintah. Hal ini juga dibenarkan dalam undang-undang nomor 20 tahun 2003 tentang sistem pendidikan nasional pasal 36 ayat 2 yang menyebutkan bahwa kurikulum pada semua jenjang dan jenis pendidikan dikembangkan sesuai dengan satuan pendidikan dan dikembangkan dengan prinsip diversifikasi sesuai dengan satuan pendidikan, potensi daerah dan peserta didik (KEMENDIKNAS, 2003: IO). Hal ini membuat sekolah alam ungaran SAUNG menciptakan kreatifitas dalam merancang kurikulum guna menjadikan alam sebagai media pembelajaran yang utama. Kurikulum yang ada dijadikan rujukan lalu dibuatlah kurikulum yang lebih disesuaikan dengan kondisi alam.

Pengkondisian kurikulum dilakukan untuk menciptakan suatu pola pembelajaran yang teratur dan sistem pembelajaran yang kuat. Pola pembelajaran tersebut nantinya akan membuat kepala sekolah, guru dan siswa dapat mengikutinya yang disesuaikan dengan karakter yang ingin dihasilkan oleh sekolah. Karakter yang dihasilkan oleh sekolah sangat tergantung pada sistem kurikulum hingga perangkat pembelajaran dalam proses pembelajaran di dalam kelas. Maka dari infromasi yang diberikan oleh kepala sekolah telah dijelaskan bahwa karakter yang ingin dihasilkan dari siswa siswi SD Alam Ungaran dimulai dari menciptakan anak-anak yang berakhlakul 
karimah, mampu menerapkan logika berpikir ilmiah dan memiliki jiwa kepemimpinan yang baik. Karakter inilah yang diharapakan oleh SD Alam Ungaran dapat tercipta pada seluruh anak didik.

Guna menciptakan 3 karakter tersebut maka anak-anak didekatkan dengan alam sebagai wadah yang sangat mereka kenali. Alam telah menjadi tempat bermain yang telah menemani keseharian anak dimulai dari masa kanak-kanak, kecil hingga dewasa kelak. Untuk itu media alam menjadi media yang mudah dicerna oleh siswa dalam menjelaskan mata pelajaran yang akan disampaikan di sekolah. Ini semua terjadi karena media-media yang diajarkan cukup dikenali siswa baik dalam keseharian di rumah maupun di lingkungan sekolah.

Maka untuk mengimplementasikan media alam dalam pembelajaran PAI dalam proses pembelajaran terlebih dahulu para guru akan membuat spyder web yang berfungsi untuk mengintegrasikan berbagai mata pelajaran pada satu tema. Setelah spyder web selesai maka guru akan membuat weekly sebagai bagian perangkat pembelajaran yang berisi kegiatan siswa, media pembelajaran dan indikator yang ingin dicapai dalam pembelajaran. Tahap terakhir para guru akan membuat daily sebagai rencana pembelajaran saat mengajar di sekolah. Inilah perangkat pembelajaran yang disusun oleh guru yang secara istilah berbeda dengan perangkat pembelajaran yang diterapkan oleh guru secara umum. Guru-guru di sekolah biasanya menggunakan perangkat silabus,PROTA PROMES dan RPP. Namun, istilah-istilah tersebut sedikit berbeda dengan perangkat pembelajaran yang diterapkan di sekolah alam. Silabus yang sering dipakai oleh guruguru di sekolah umum oleh guru-guru sekolah alam bernama spyder web. Untuk PROTA di sekolah alam lebih dikenal dengan nama weekly sedangkan RPP (Rencana Perangkat Pembelajaran) oleh sekolah alam disebut daily.

Perangkat-perangkat pembelajaran tersebut dibuat dengan menjadikan tema pembelajaran sebagai patokanya. Tema inilah yang akan dijabarkan dalam bentuk weekly hingga daily. Daily akan membantu guru dalam proses pembelajaran dan guru merancang proses pembelajaran di dalamnya. Selain berbasis pada masalah yang sering terjadi di sekelilingnya, implementasi media alam yang berbasis masalah akan membawa fikrah anak didik secara lebih aktual. Karena anak-anak akan memahami hikmah dari proses pembelajaran yang telah diberikan dengan sangat mudah karena masalah-masalah yang sering dialami di masyarakat dapat terpecahkan dalam proses pembelajaran. Selanjutnya hal itu akan mengasah anak untuk memiliki pola kepemimpinan yang baik dalam bertidak baik kepada dirinya, orang tua dan orang lain. Anakanak akan mampu membedakan sisi positif dan negatif sebelum melakukan segala sesuatu. Hal inilah yang merangsang anak didik untuk terus menjadi khalifah di muka bumi. Karena mereka dilatih untuk melihat kekuasaan Allah dan menjaganya melalui ciptaan alam yang sangat indah.

a) Teknik Penggunaan Media Alam

Dalam menjalankan proses pembelajaran di sekolah alam ungaran maka diperlukan kreatifitas dalam mengenalkan alam kepada siswa. Sekolah alam ungaran telah menerapkan pembelajaran dengan 
penggunaan teknik penggunaan media yang baik. Kreatifitas guru dalam mengajarkan mata pelajaran PAI dan DIKNAS dengan menggunakan teknik berkebun, outting, out bond, MABIT dan cooking.

MABIT dilakukan setiap akhir semester sedangkan outting dan cooking dilaksanakan setiap hari selasa dan rabu. Untuk kegiatan berkebun dilakukan di hari jumat pagi. Selain itu kegiatan out bond dilakukan setiap sebulan sekali. Kegiatan outting diawali dengan menyusun daily plan yang tepat dengan mata pelajaran yang akan diajarkan. Lalu disusunlah surat izin dan waktu yang tepat untuk menentukan tempat.

Dalam pelaksanaan outting, cooking, berkebun, MABIT dan out bond guru melakukan beberapa hal yaitu pertama, seorang guru harus mengetahui tujuan dari proses pembelajaran tersebut. Kedua ,indikator apa saja yang akan dicapai oleh siswa. Setiap pemanfaatan media alam dalam bentuk program sekolah dilakukan dengan menetukan tujuan pembelajaran terlebih dahulu. Setelah itu indikator pencapaian proses pembelajaran hendaklah dapat ditentukan dengan melihat tujuan pembelajaran yang akan didapatkan. Hal ini sangat berpengaruh pada hasil pembelajaran.

b) Prosedur penggunaan media alam Guna menghasilkan anak-anak yang berkarakter cinta lingkungan maka setiap guru akan merancang pembelajaran dengan menggunakan media alam. Pembelajaran dengan menggunakan media alam tergambar dalam daily yang telah dirancang oleh guru. Dalam pembuatan media alam, guru diwajibkan mengetahui indikator yang akan dicapai.
Setiap guru harus mengetahui tujuan dari setiap materi pembelajaran yang diberikan di dalam kelas. Karena tujuan akan mengarahkan hasil yang akan dicapai oleh siswa dalam setiap pembelajaran dengan menggunakan media alam. Tujuan yang baik akan tergambar pada indikator-indikator yang dibuat oleh guru sehingga guru dapat menentukan media yang tepat dalam proses pembelajaran. Media yang tepat bersifat kreatif dan mudah didapatkan oleh guru. Hal ini dilakukan agar merangsang siswa untuk mempraktekannya di rumah dan membangun kesungguhan anak untuk belajar. Oleh karena itu media alam haruslah bersifat kreatif baik dalam penampilanya maupun dalam proses pembelajaran yang akan diberikan kepada siswa.

Guna menciptakan karakter akhlakul karimah dalam penerapan media alam maka para guru dituntut untuk memunculkan beberapa ayat atau hadist Rasullulah Saw dalam setiap pembelajaran. Perangkat pembelajaran tersebut dinamakan daily. Daily berisi hal-hal yang berkaitan dengan tujuan, indikator pembelajaran, metode mengajar dalil Al quran dan hadist Rasullulah SAW. Dalil Al Quran bersifat wajib dalam setiap daily pembelajaran. Hal ini bertujuan untuk mengingatkan siswa bahwa mereka hanyalah hamba Allah SWT yang diutus sebagai khalifah. Maka sangat mendasar jika karakter akhlakul karimah menjadi karakter yang diharapkan muncul pertama kali di dalam diri siswa.

Oleh karena itu, peran media alam dalam pembelajaran pendidikan agama Islam akan mengantarkan siswa menuju pemahaman yang utuh terhadap penciptaan alam. Selain 
itu media alam sangat mempengaruhi proses pembelajaran di sekolah. Karena media alam akan menentukan respon siswa dan semangat siswa dalam menghadapi pelajaran di sekolah. Guna menghindari itu, maka guru hendaknya membuat daily yang bersifat kreatif dan inovatif. Salah satu syarat terpenuhinya nilai kreatifitas dan inovasi sebuah media adalah bahan dan alat media yang mudah didapatkan di alam atau lingkungan sekolah. Indikator selanjutnya dari implementasi media alam terhadap pembelajaran pendidikan agama Islam adalah dimasukanya ayat-ayat Al Qur'an dan hadist-hadist Nabi Muhammad SAW dalam setiap kegiatan pembelajaran di sekolah. Maka penunjang dari penerapan media yang maksimal hendaknya seorang guru dapat melihat tujuan pembelajaran yang ingin dicapai, indikatornya dan metode pembelajaranya. Jika hal ini telah dilakukan maka karakter akhlakul karimah, kepemimpinan dan logika berpikir ilmiah akan dapat dihasilkan oleh SD Alam Ungaran.

2. Efektifitas Media Mlam dalam PAI di SD Alam Ungaran

Media alam dalam pembelajaran PAI di SD Alam Ungaran bersifat alat belajar. Karena media alam menjadi alat belajar yang membantu siswa dan guru dalam melaksanakan proses pembelajaran. Dengan tidak adanya media alam tersebut maka guru di sekolah alam masih bisa mencari media pembelajaran yang sesuai untuk melakukan pembelajaran di sekolah. Alasan lainya ialah para guru yang memiliki banyak pilihanpilihan guna mendapatkan pembelajaran yang lebih maksimal. Untuk itu, setiap guru harus mengetahui tujuan dari setiap pembelajaran dan menyusun setiap proses pembelajaran secara kreatif dan inovatif.

Selain itu, efektifitas media alam di sekolah alam ungaran juga dapat dilihat dari beberapa program mengajar yang bersifat out door. Program ini mengajak siswa ke luar kelas dan sekolah untuk mengamati beberapa peristiwa alam misalnya mengamati arus sungai, membersihkan sampah sungai, mengamati sawah, pohon dan berbagai ciptaan Allah SWT. Dalam proses pembelajaran juga menggunakan mediamedia yang mudah didapatkan agar siswa tidak hanya memahami pelajaran di sekolah tapi juga mampu mempraktekanya di rumah.

Maka media alam bersifat fleksibel, tidak kaku dan luas. Hal inilah yang membuat pelajaran di sekolah alam terlihat mudah dan menyenangkan. Anakanak tidak dididik untuk harus memahami setiap mata pelajaran dengan baik seperti sekolah lain pada umumnya. Akan tetapi anak-anak dididik untuk mengamalkan setiap ilmu yang mereka dapatkan di sekolah. Untuk itu, anak-anak di sekolah alam diharapkan memiliki karakter berpikir ilmiah, kepemimpinan dan akhlak yang mulia sehingga SD Alam Ungaran mendahulukan pada pembentukan karakter anak bukan pada pembentukan sisi kognitif. Selain itu, SD Alam ungaran tidak memiliki KKM (Ketentuan Ketuntasan Mengajar) seperti sekolah lain pada umumnya. Karena SD Alam Ungaran lebih mendahulukan pembentukan karakter, akhlak mulia dan logika berpikir ilmiah.

Logika berpikir ilmiah juga dibuat secara seimbang dan tidak mengekang siswa dalam 
setiap mata pelajaran. Karena mata pelajaran yang diberikan tidak mengeksplorasi sisi kognitif anak dengan mempelajari lebih mendalam setiap mata pelajaran. Akan tetapi guru mengintegrasikan beberapa mata pelajaran yang tergambar dalam spyder web. Setelah melalui spyder web maka setiap guru akan membuat program semester untuk 6 bulan ke depan. Dalam masa enam bulan inilah guru akan mengadakan beberapa program yaitu cooking, market day, tema dan outing, mabit dan berkebun. Lalu program pembelajaran tersebut direncanakan kembali dalam kegiatan pekanan atau disebut weekly. Weekly menggambarkan kegiatan siswa per pekan yang juga di dalamnya tertuang waktu, mata pelajaran dan kegiatan pembelajaran pada siswa. Lalu dibuatlah daily atau rencana pelaksanaan pembelajaran (RPP) yang di dalamnya terdapat jam mengajar, kegiatan, indikator hasil belajar, sumber belajar dan deskripsi kegiatan mengajar di sekolah.

Setelah itu, media alam dihubungkan dengan berbagai mata pelajaran dan salah satunya ialah pendidikan agama Islam. Untuk melihat efektifitas media alam dalam pembelajaran pendidikan agama Islam maka guru pertama kali akan melihat pemahaman siswa setelah mengikuti proses pembelajaran. Guru akan membuat lembar kerja (LK) yang berfungsi untuk mengevaluasi kegiatan belajar mengajar yang telah berlangsung. Di dalam lembar kerja (LK) terdapat berbagai pertanyaan berdasarkan hasil observasi murid setelah mengikuti proses pembelajaran. Dalam lembar kerja (LK) sekolah alam ungaran tidak menggunakan KKM sebagai parameter yang harus dituntaskan siswa. Siswa dinilai berdasarkan pemahaman dan analisis deskripsi mereka tentang halhal yang telah dipelajari sebelumnya. Hal ini menyebabkan anak-anak tidak merasa terkekang dan tertekan oleh mata pelajaran. Mereka akan menjadi pribadi yang bebas dan mencintai sekolah karena banyak hal menyenangkan di dalamnya.

Untuk menjaga konsistensi hasil belajar siswa maka sekolah alam ungaran membuat laporan hasil belajar siswa setiap bulan. Hal ini dilakukan untuk melihat perkembangan siswa sekaligus menjadi monitoring bersama antara guru dan wali murid. Di dalam laporan hasil belajar yang diberikan tiap bulan dijelaskan beberapa potensi siswa seperti ibadah, kepemimpinan, pengetahuan umum, market day dan kecerdasan majemuk yang dimiliki siswa. Kebijakan ini cukup efektif karena pola perkembangan siswa akan selalu terkontrol dan dilihat oleh guru dan orang tua. Orang tua akan melakukan pola didik yang jauh lebih inovatif untuk mrngontrol perilaku siswa dan menjaga anak didik dari melakukan hal-hal yang yang kurang baik.

\section{KESIMPULAN}

- Data telah dianalisis dan dipaparkan dengan temuan-temuan yang dihasilkan ke dalam penelitian ini. Ada beberapa rumusan masalah dalam penelitian ini, yaitu: (I) Implementasi media alam dalam pembelajaran Pendidikan Agama Islam (PAI) di SD Alam Ungaran (SAUNG), (2) Efektifitas media alam dalam pembelajaran Pendidikan Agama Islam (PAI) di SD Alam Ungaran (SAUNG). Adapun kesimpulan dari penelitan ini adalah sebagai berikut:

I. Pemanfaatan media alam dalam pembe- 
lajaran Pendidikan Agama Islam (PAI) dilakukan dengan menggunakan cara spyder web, weekly, daily dan lembar kerja (LK). Lalu dijabarkan ke dalam kegiatan MABIT, Outing, Outbond, Berkebun, Market Day dan cooking. Berbagai kegiatan tersebut menggunakan media alam dengan menambahkan ayat-ayat Al-qur'an dan hadist nabi Muhammad Saw.

2. Efektifitas media alam dalam pembelajaran PAI membuat anak-anak menjadi nyaman untuk mempelajari Pendidikan Agama Islam hal ini disebabkan karena ayat-ayat Al Quran dan hadist Nabi Muhammad Saw tidak mengekang siswa di sekolah. Selain itu, media alam yang digunakan untuk mengajarkan Pendidikan Agama Islam (PAI) tidak memiliki KKM (Ketuntasan Kinerja Mengajar) yang membuat guru terkadang memaksakan setiap mata pelajaran PAI untuk dikuasai secara utuh. Maka evaluasi dari setiap pertemuan dinilai dalam bentuk lembar kerja (LK) yang didalamnya sudah di integrasikan pendidikan agama Islam dalam bentuk menyebutkan ayat-ayat Allah dan hadist Nabi yang berkaitan dengan tema yang telah dipelajari sebelumnya.

\section{DAFTAR PUSTAKA}

Ahmad. 2005.Ilmu Pendidikan Islam.Jakarta : Lembaga Pendidikan Umat

Kementerian Pendidikan Nasional.2003. Undang-undang No. 20 tahun 2003 tentang sistem pendidikan nasional. Jakarta:Direktorat Pendidikan Nasional

Komunitas sekolah alam.2005.Menemukan sekolah yang membebaskan.
Tanggerang:PT. Kawan Pustaka

Nafisah, zohratun.20I0.Studi Manajemen Kelas di SD Sekolah Alam (SAUNG) Ungaran (Skripsi).Semarang:Fakultas Tarbiyah Institut Agama Islam Negeri Semarang 
